\title{
A Case of Milk Producers Perception towards Extent of Input Supply and Preventive Services by Milk Marketing Agencies in Salem District of Tamilnadu, India
}

\author{
R. Sangameswaran ${ }^{1 *}$ and Sunitha Prasad ${ }^{2}$ \\ ${ }^{1}$ Department of Veterinary and Animal Husbandry Extension education, VCRI, Tirunelveli, \\ Tamil Nadu, India \\ ${ }^{2}$ Department of Veterinary and Animal Husbandry Extension education, NTR CVSc., \\ Andhra Pradesh, India \\ *Corresponding author
}

\section{Keywords}

Milk Producers

Perception,

Milk Marketing

Agencies

Article Info

Accepted:

12 February 2018

Available Online:

10 March 2018

\section{A B S T R A C T}

In pursuit of increasing milk production among other factors, adequate and timely supply of quality inputs, disease surveillance and preventive service delivery is inevitable. Veterinary services for milk producers in general and Supply of Inputs and Preventive services in particular have traditionally been provided by the public sector at institution, but milk marketing agencies viz dairy development department and private agency have extended their provision at village level but limited their availability of services at centre only. This paper considers the extent of Input supply and preventive service delivery and milk producers' perception about quality, timeliness and service charge paid to gain an insight into the debatable issue of effective and efficient service delivery as claimed by the service providers. These results underline the need for a re-examination of the milk procurement agencies strategy to ensure supply of inputs and preventive services to the rural milk producers as and when they need. It is time to ensure in-time availability of inputs and preventive services, through either 'user pays' fees or levies. In the long term, as the dairy sector develops and service delivery becomes inevitable, dairy development department will need to dedicate itself towards playing valuable role in providing quality and timely inputs, animal disease surveillance and control.

\section{Introduction}

The services in animal health, production, extension and market need to enhance the capacity of poor households to exploit the full potential of livestock Production (Ahuja and
Redmond, 2001). Several studies of researchers claimed that livestock rearing has significant positive impact on equity in terms of income, employment and poverty reduction in rural areas (Singh and Hazell, 1993; Thornton et al., 2002 and Birthal and Ali, 
2005). In India veterinary services have been traditionally funded, managed and delivered by the Department of Animal Husbandry with significant subsidies or on free basis (Kumar et al., 2006, Shweta, 2014; Ahuja et al., 2008). The demand for livestock service delivery is increasing because of increase in population and improved livelihoods. Among various services, an effective and efficient input and preventive service delivery is of paramount importance for rural milk producers. Timely and adequate supply of quality inputs and services to farmers is a pre-requisite for increasing production (Chand et al., 2014). However, the ability of the milk marketing agency to attract the milk producers to pour milk to their pot is influenced by the extent of availability and accessibility of services delivered to the rural milk producers. A significant impact of the supply of inputs and preventive service delivery can be evaluated by studying the availability, accessibility, milk producers' preference and identifying determinants that influence their preference to avail the services. This paper focuses on the extent of Inputs supply and vaccination services by milk marketing agency, identifying factors influencing the milk producers in preferring the service agency for these services and satisfaction of milk producers in availing the services.

\section{Materials and Methods}

The present study was conducted in the selected five blocks of Salem district of Tamil Nadu. Salem district was selected purposively as it stands first in milch animal population and milk production in Tamil Nadu Purposive and multistage random sampling procedures were followed for selection of study area and respondents. The data were collected with the help of pre-structured interview schedule through personal interview method from 150 milk producers ( 75 milk producers from DCS and 75 milk producers from Private).
Secondary data regarding the modus operandi of the selected marketing agencies were collected. Preference of milk producers and twelve socio-economic indicators were considered as consequent and antecedent variables respectively. The collected data were tabulated, computed and analyzed statistically by Principle component analysis and varimax rotation method (factor analysis) by SPSS software. The interpretation of factor analysis is based on rotated factor loadings, extracted communality and rotated Eigen value.

The categorized factors were named based on pragmatic reasoning. Data regarding satisfaction level of the respondents with respect to quality, timeliness and amount of fee paid for services were collected from the respondents in three continuum scale were tabulated, computed and analysed.

\section{Results and Discussion}

The organisation of this paper is as follows (1) Inputs supply and preventive services of milk marketing agency-modus operandi Perception of milk producers regarding accessibility of services followed by identifying factors influencing preference of milk producers to avail these services (3) Satisfaction of milk producers in terms of quality, timeliness and amount of fee paid for availing the services.

\section{Inputs supply and preventive services of milk marketing agency-Modus operandi}

The agencies claimed that they were providing various services for the benefit of the milk producers. The respondents also perceived that the services were available at the institution level. But, the extent to which these services are accessible to the milk producers can indicate a true picture of these services. Most of the services may be available but their accessibility was limited to some members. 


\section{Dairy co-operatives}

The inputs such as feed, fodder slips, fodder seeds and mineral mixture were supplied to the milk producers to enhance milk production. The Salem union is supplying two types of feeds viz., IPL and Aavin to the elite and interested dairy farmers on payment. The fodder slips were supplied to the members at nominal cost. Similarly, seeds of fodder sorghum and mineral mixture were also supplied at free of cost to the milk producers through the respective PMCS.

\section{Private milk procurement agency}

Inputs such as feed, fodder slips, fodder seeds and mineral mixture were supplied to the milk producers. The private agency supplied cattle feed @ Rs. 12.5 per $\mathrm{kg}$ to its member producers. It also supplied fodder slips @ Rs. 100 per 1000 slips. Similarly fodder sorghum seeds (COFS) @ Rs.250/kg, desmanthus seeds @ Rs.250/kg and fodder sorghum (ordinary variety) @ Rs. 30/kg were supplied to the interested milk producers. Three different varieties of mineral mixture viz., Kemetrace, E-sac and Ultramin were sold to the interested farmers@ @s.80, Rs. 110 and Rs.64 respectively by the agency.

\section{Preventive services}

\section{Dairy co-operatives}

Deworming medicines were provided to the PMCS secretary and VLWs for deworming the animals of the member producers at free of cost. The cattle were vaccinated against some important diseases with the help and cooperation from the DAH.

Veterinary Consultants and VLWs usually organize vaccination campaigns in the villages for the member producers in consultation with the DAH.

\section{Private milk procurement agency}

The preventive services such as vaccination and deworming to the cattle were undertaken by the private agency which was similar to that of co-operative agency. Deworming medicines were provided to the milk collection centre in-charge and inseminators for deworming animals of member producers at free of cost. Vaccination services to the animals of member producers were usually arranged from DAH.

\section{Perception of milk producers regarding accessibility of services}

\section{Input services}

Access to services can be examined in two different ways. First, by specifically asking the non-users why they did not use the service during the reference period of the survey, and second, by directly asking all the respondents whether they would be able to obtain the service as and when they need it. When it comes to the supply of inputs, both the milk marketing agencies were supplying them at different rates as perceived by the respondents (Table 1). These inputs include cattle feed, fodder slips/ seeds and mineral mixture. In all the selected villages the agri by-products such as coconut oil cake and rice bran were available to the farmers who were growing coconut and rice in their fields. It is also learnt from the respondents that all these agencies including DAH supplied these inputs only to limited number of respondents and that too at their respective institution.

\section{Preventive services}

\section{Vaccination}

The data in Table 2 showed DAH was the only agency providing vaccination services to the milk producers in all the selected villages. 
Table.1 Accessibility of inputs as perceived by the respondents

\begin{tabular}{|c|}
\hline $\begin{array}{c}\text { Selected } \\
\text { villages }\end{array}$ \\
\hline V1 \\
\hline V2 \\
\hline V3 \\
\hline V4 \\
\hline V5 \\
\hline
\end{tabular}

\begin{tabular}{|c|c|}
\hline \multicolumn{2}{|c|}{ DCS } \\
\hline Door step & Centre \\
\hline X & $\checkmark$ \\
\hline X & $\checkmark$ \\
\hline X & $\checkmark$ \\
\hline X & $\checkmark$ \\
\hline X & $\checkmark$ \\
\hline
\end{tabular}

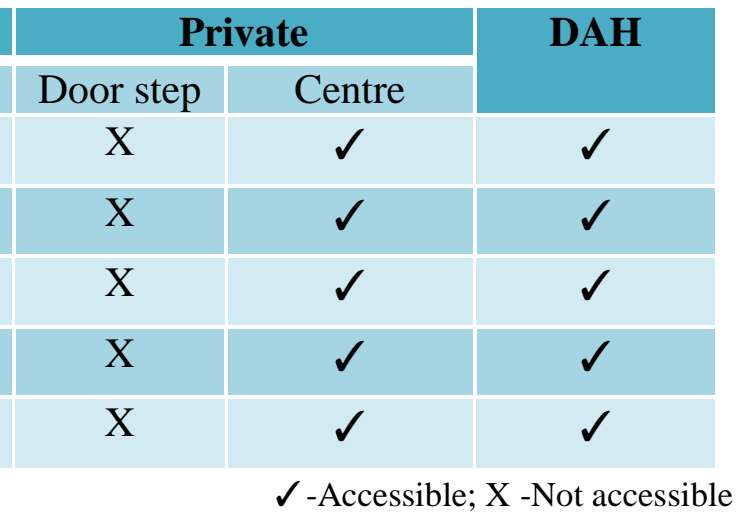

Table.2 Accessibility of vaccination services as perceived by the respondents

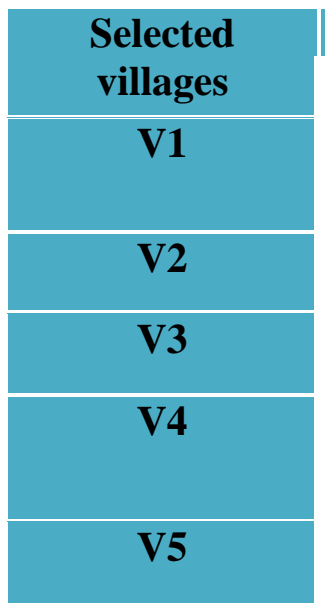

\begin{tabular}{|c|c|c|c|c|}
\hline \multicolumn{2}{|c|}{ DCS } & \multicolumn{2}{c|}{ Private } & DAH \\
\hline Door step & Centre & Door step & Centre & \\
\hline X & X & X & X & $\checkmark$ \\
\hline X & X & X & X & $\checkmark$ \\
\hline X & X & X & X & $\checkmark$ \\
\hline X & X & X & X & $\checkmark$ \\
\hline X & & & & \\
\hline
\end{tabular}

Table.3 Accessibility of deworming services as perceived by the respondents

\begin{tabular}{|c|c|c|c|c|c|}
\hline \multirow{2}{*}{$\begin{array}{c}\text { Selected } \\
\text { village }\end{array}$} & \multicolumn{2}{|c|}{ DCS } & \multicolumn{2}{c|}{ Private } & DAH \\
\hline V1 & Door step & Centre & Door step & Centre & \\
\hline V2 & X & $\checkmark$ & X & $\checkmark$ & $\checkmark$ \\
\hline V3 & X & $\checkmark$ & X & $\checkmark$ & $\checkmark$ \\
\hline V4 & X & $\checkmark$ & X & $\checkmark$ & $\checkmark$ \\
\hline V5 & X & $\checkmark$ & X & $\checkmark$ & $\checkmark$ \\
\hline
\end{tabular}


Table.4 Factor analysis of predictor variables influencing preference of milk producers of DCS for availing Input services

\begin{tabular}{|l|l|l|l|l|l|}
\hline Factor & Variables & $\begin{array}{l}\text { Factor } \\
\text { Loading }\end{array}$ & $\begin{array}{l}\text { Eigen } \\
\text { Value }\end{array}$ & $\begin{array}{l}\text { Variance } \\
\text { contribution } \\
(\%)\end{array}$ & Communality \\
\hline $\mathbf{1}$ & Milk Production(X9) & 0.854 & 4.420 & 31.576 & 0.899 \\
\hline Milk Sales (X11) & 0.850 & & & 0.893 \\
\hline Income From Agriculture (X7) & 0.774 & & & 0.668 \\
\hline Land Holding (X4) & 0.769 & & & 0.655 \\
\hline Herd Size (X6) & 0.766 & & & 0.632 \\
\hline Income From Dairying (X8) & 0.705 & & & 0.668 \\
\hline $\mathbf{2}$ & Family Size(X2) & 0.737 & 3.871 & 27.660 & 0.580 \\
\hline Experience In Dairying (X5) & 0.697 & & & 0.547 \\
\hline Milk Consumption (X10) & 0.582 & & & 0.666 \\
\hline $\begin{array}{l}\text { Distance Of Milk Procurement } \\
\text { Centre(X12) }\end{array}$ & 0.624 & 5.976 & 42.689 & 0.617 \\
\hline Education(X3) & & & & 0.595 \\
\hline Age(X1) & 0.619 & & & 0.680 \\
\hline
\end{tabular}

Table.5 Factor analysis of predictor variables influencing preference of milk producers of DCS for availing Preventive services

\begin{tabular}{|c|c|c|c|c|c|}
\hline $\begin{array}{l}\text { Facto } \\
\mathbf{r}\end{array}$ & Variables & $\begin{array}{l}\text { Factor } \\
\text { Loading }\end{array}$ & $\begin{array}{l}\text { Eigen } \\
\text { Value }\end{array}$ & $\begin{array}{l}\text { Variance } \\
\text { Contributio } \\
\text { n }\end{array}$ & Communality \\
\hline \multirow[t]{6}{*}{1} & Milk Sales (X11) & 0.903 & \multirow[t]{6}{*}{4.483} & \multirow[t]{6}{*}{32.02} & 0.906 \\
\hline & Milk Production (X9) & 0.901 & & & 0.911 \\
\hline & Herd Size (X6) & 0.809 & & & 0.682 \\
\hline & Income from Dairying (X8) & 0.669 & & & 0.669 \\
\hline & Land Holding (X4) & 0.658 & & & 0.713 \\
\hline & Income from Agriculture (X7) & 0.646 & & & 0.777 \\
\hline \multirow[t]{2}{*}{2} & Experience in Dairying (X5) & 0.711 & \multirow[t]{2}{*}{1.555} & \multirow[t]{2}{*}{11.10} & 0.581 \\
\hline & Distance Of MPC(X12) & 0.702 & & & 0.571 \\
\hline \multirow[t]{3}{*}{3} & Milk Consumption (X10) & 0.725 & \multirow{3}{*}{6.090} & \multirow[t]{3}{*}{43.50} & 0.691 \\
\hline & Family Size(X2) & 0.597 & & & 0.594 \\
\hline & $\operatorname{Age}(\mathrm{X} 1)$ & -0.416 & & & 0.704 \\
\hline
\end{tabular}


Table.6 Factor analysis of predictor variables influencing preference of milk producers of private agency for availing input services

\begin{tabular}{|c|c|c|c|c|c|}
\hline Factor & Variables & $\begin{array}{l}\text { Factor } \\
\text { Loading }\end{array}$ & $\begin{array}{l}\text { Eigen } \\
\text { value }\end{array}$ & $\begin{array}{l}\text { Variance } \\
\text { contribution } \\
(\%)\end{array}$ & Communality \\
\hline \multirow[t]{4}{*}{1} & Milk sales(X11) & 0.963 & \multirow[t]{4}{*}{2.13} & \multirow[t]{4}{*}{16.39} & 0.945 \\
\hline & Milk production(X9) & 0.957 & & & 0.945 \\
\hline & Income from dairying(X8) & 0.853 & & & 0.746 \\
\hline & Herd size(X6) & 0.643 & & & 0.494 \\
\hline \multirow[t]{2}{*}{2} & Income from agriculture(X7) & 0.888 & \multirow[t]{2}{*}{2.25} & \multirow[t]{2}{*}{17.35} & 0.857 \\
\hline & Land holding(X4) & 0.870 & & & 0.793 \\
\hline \multirow[t]{5}{*}{$\overline{3}$} & Education (X3) & 0.801 & \multirow[t]{5}{*}{8.18} & \multirow[t]{5}{*}{62.96} & 0.661 \\
\hline & $\operatorname{Age}(\mathrm{X} 1)$ & -0.670 & & & 0.492 \\
\hline & Family Size(X2) & 0.624 & & & 0.543 \\
\hline & Experience in dairying(X5) & -0.411 & & & 0.235 \\
\hline & Milk consumption $(\mathrm{X} 10)$ & 0.710 & & & 0.639 \\
\hline
\end{tabular}

Table.7 Factor analysis of predictor variables influencing preference of milk producers of private agency for availing preventive services

\begin{tabular}{|c|c|c|c|c|c|}
\hline Factor & Variables & $\begin{array}{c}\text { Factor } \\
\text { Loading }\end{array}$ & $\begin{array}{l}\text { Eigen } \\
\text { Value }\end{array}$ & $\begin{array}{c}\text { Variance } \\
\text { Contribution } \\
(\%)\end{array}$ & Communality \\
\hline \multirow[t]{4}{*}{1} & Milk Sales(X11) & 0.948 & \multirow[t]{4}{*}{2.62} & \multirow[t]{4}{*}{18.74} & 0.942 \\
\hline & Milk Production(X9) & 0.946 & & & 0.941 \\
\hline & Income from Dairying $(X 8)$ & 0.881 & & & 0.831 \\
\hline & Herd Size(X6) & 0.628 & & & 0.473 \\
\hline \multirow[t]{2}{*}{2} & Income from Agriculture $(X 7)$ & 0.888 & \multirow[t]{2}{*}{2.19} & \multirow[t]{2}{*}{15.66} & 0.895 \\
\hline & Land Holding(X4) & 0.882 & & & 0.812 \\
\hline \multirow[t]{3}{*}{3} & Education(X3) & 0.772 & \multirow[t]{3}{*}{7.16} & \multirow[t]{3}{*}{51.14} & 0.659 \\
\hline & $\operatorname{Age}(X 1)$ & -0.704 & & & 0.544 \\
\hline & Family size & 0.681 & & & 0.534 \\
\hline \multirow[t]{2}{*}{4} & Experience in Dairying(X5) & 0.801 & \multirow[t]{2}{*}{1.56} & \multirow[t]{2}{*}{11.21} & 0.758 \\
\hline & Distance of MPC(X12) & 0.617 & & & 0.659 \\
\hline
\end{tabular}

Table.8 Satisfaction on quality, timeliness and service charges of Input and Preventive services provided by the marketing agencies

\begin{tabular}{|c|l|c|c|c|c|c|c|}
\hline S. No & \multicolumn{1}{|c|}{ Services } & \multicolumn{2}{|c|}{ Quality } & \multicolumn{2}{c|}{ Timeliness } & \multicolumn{2}{|c|}{ Service Charges } \\
\hline 1 & Deworming & $4(4)$ & $7(7)$ & $04(4)$ & $7(7)$ & $04(04)$ & $07(07)$ \\
\hline 2 & Supply of cattle feed & $15(16)$ & $11(11)$ & $16(16)$ & $11(11)$ & $12(16)$ & $08(11)$ \\
\hline 3 & Supply of fodder slips & $2(2)$ & $3(3)$ & $2(2)$ & $3(3)$ & $02(02)$ & $03(03)$ \\
\hline
\end{tabular}

*Figures in Parenthesis indicate the number of respondents availed the services 
As indicated earlier the milk marketing agencies organize vaccination campaigns in their respective villages with the involvement of the staff of DAH. This finding is similar to the observation of Umali et al., (1992) who reported that in majority of the countries, public sector was the main service provider for vaccination support to the livestock farmers.

\section{Deworming}

The respondents perceived that all the agencies including DAH were providing the deworming services to the milk producers only at their respective institutions (Table 3 ).

These agencies organized campaigns in the villages to control the internal parasites in dairy cattle and to treat the sick or infertile animals. The main difference was that the DAH provided deworming services to all the livestock owners including poultry farmers whereas the milk marketing agencies target only the dairy farmers. The respondents also do not consider deworming as an important activity and hence do not approach the private practitioners for deworming their animals as a preventive measure. With respect to services such as deworming, supply of cattle feed and supply of fodder slips, the number of respondents who availed the services was very low mainly because these services were accessible dairy farmers at centre only.

Identification and prioritization of different factors influencing Preference of milk producers of DCS in availing Input services

The data regarding factor loading, communality of variables, Eigen value and variance contribution of each factor influencing preference of milk producers of DCS to avail input services were presented in Table 4.
The first factor influencing preference encompassed six variables viz., milk production (0.854), milk sales (0.850), income from agriculture $(0.774)$, land holding (0.769), Herd size (0.766), income from dairying (0.705) and the factor was re-named as "economic capital". It explained $31.57 \%$ of variance with Eigen value 4.42. The second factor influencing preference was named as "socio-personal attributes" as it had with three variables viz., family size (0.737), experience in dairying (0.697) and Milk consumption (0.582). This factor explained 27.66 per cent of variance with Eigen value 3.87. The third factor influencing preference encompassed with three variables, age (0.821) and education (0.619) and distance of farm home from milk procurement centre (0.624). The factor was named as "socio-personal and situational attributes". It explained the highest percentage of variance $(42.68 \%$ ) and eigen value of 5.97. All the three factors exerted positive factor loadings which depicted that the above renamed variables exerted direct influence in DCS milk producers' preference to avail input services.

Identification and prioritization of different factors influencing Preference of milk producers of DCS in availing Preventive services

The data regarding factor analysis for conglomeration of socio-economic variables to form a homophiles factors influencing milk producers preference to avail preventive services was presented in Table 5.

The first factor was reticulated with six variables viz., milk sales (0.903), milk production (0.901), income from dairying (0.669), herd size (0.809), income from agriculture (0.646) and land holding (0.658). The factor was named as "livestock Capital" which explained 32.02 per cent variance and eigen value of 4.48. The second factor 
comprised of two variables viz., experience in dairying (0.711) and distance of farm home from milk procurement center (0.702). The factor was named as "situational variables" which explained 11.10 per cent of variance with Eigen value 1.55. The third factor comprised of three variables viz., milk consumption (0.725), family size (0.597) and age (-0.416). The factor was named as "sociopersonal variables". It explained the highest percentage of variance (43.50) with eigen value 6.09. Age exerted negative factor loading which depicted that it negatively influenced milk producers' preference in availing preventing services. Whereas other variables of all the factors had positive loading to the said factor indicated that it had direct influence on milk producers' preference in availing Preventive services.

Identification and prioritization of different factors influencing Preference of milk producers of private agency in availing input services

The data regarding factor analysis of each factor influencing preference of milk producers of private agency to avail Input services were presented in Table 6.

The first factor was named as "livestock Capital" as it comprised of four variables namely milk sales (0.963), milk production (0.957), income from dairying (0.853), herd size (0.643). It exerted the variance of sixteen per cent with Eigen value 2.13. The second factor has reticulated with two variables viz., income from agriculture (0.888) and land holding (0.870). The factor was named as "land capital" which explained (17.35) in total variance and Eigen value of 2.25. The third factor explained highest percentage of variance $(32.57 \%)$ which may be named as "socio-personal and Situational attributes". It consisted of four variables, namely family size (0.624), age (-0.670), experience in dairying (-0.411) and milk consumption (0.710). Milk producers' age and experience in dairying was negatively associated with the said attribute explained the hindrance feature in milk producers' preference to avail Input services. Sangameswaran and Sunitha Prasad (2016) reported that around 90 per cent of the milk producers of co-operatives and private agency in Salem district were expecting credit from their agencies during exigencies.

\section{Identification and prioritization of different factors influencing preference of milk producers of private in availing preventive services}

The data regarding factor analysis of each factor influencing preference of milk producers of Private agency to avail preventive services were presented in Table 7.

The first factor explained 18.74 per cent variance and eigen value 2.62 which was named as "livestock Capital". It consisted of four variables viz., milk sales (0.948), milk production (0.946), income from dairying (0.881) and herd size (0.628). The second factor was named as "land capital" had two variables viz., income from agriculture (0.888) and land holding (0.882). It explained the percentage of variance $(15.66 \%)$ and Eigen value of 2.19. All the variables related to land and livestock capital was positively associated with the said factor explained positive and breakthrough feature in milk producers' preference to avail preventive services. A glance at Table 7 showed that third factor exerted highest influence $(51.14 \%)$ in total variance and was named as "socio-personal attributes". The variables were family size (0.681), age (-0.704), education (0.772). Age was negatively associated with the socio-personal attribute which depicted the negative influence in milk producers' preference to avail preventive services. The third factor influencing 
preference of consisted of two variables viz., experience in dairying (0.801) and distance of farm home from milk procurement centre (0.617). The factor was named as "sociopersonal and situational attributes". It explained 11.21 per cent of variance and Eigen value of 1.56 .

Perception of farmers towards supply of Inputs and preventive services by milk marketing agency

Linder-Pelz (1982) postulated that satisfaction is mediated by personal beliefs and values about service as well as expectation about service. Satisfaction or dissatisfaction is the client's judgment on quality of service in all its aspect. The responses from the respondents were obtained on their extent of satisfaction in the following aspects viz., quality, Timeliness and service charges is presented in Table 8 .

All the respondents of DCS who availed deworming services (4 of 4) and received fodder slips (2 of 2) expressed their satisfaction on the quality of these services. All the respondents who availed deworming services and cattle feed were satisfied with the quality of services provided by the private agency. It is very clear from these findings that the respondents who so ever have availed the dairy husbandry services irrespective of the service provider were satisfied with the quality. All the respondents who availed deworming services and cattle feed were satisfied with the timeliness in delivering services by the private agency. All the respondents who availed deworming services and cattle feed were satisfied with the charges levied by the private agency in providing services.

The evidence presented in this paper show that all the respondents perceived that supply of inputs and preventive services particularly from milk procurement agencies are available and accessible at centre. But the findings revealed that only small number of milk producers preferred to avail these services from their milk marketing agencies. Of course socio-personal, situational attributes and economic capital have an influence on milk producers' preference for availing these services. It is interested to note that majority of the respondents were satisfied on quality, timeliness and amount of fee paid for the services. These results underline the need for a re-examination of the milk procurement agencies strategy to ensure supply of inputs and preventive services to the rural milk producers as and when they need. It is time to ensure in-time availability of inputs and preventive services. In the long term, as the dairy sector develops and service delivery becomes inevitable, dairy development department will need to dedicate itself towards disseminating better management practices by providing quality and timely inputs, animal disease surveillance and control.

\section{Acknowledgement}

The first author is greatly indebted and acknowledges Dr. K. Natchimuthu, Dr. S.V.N. Rao and Dr. S. Ramkumar of Department of AHEE, Rajiv Gandhi Institute of Veterinary and Education research, Puducherry for their guidance in this study as a part of MVSc. work.

\section{References}

Ahuja, V., Mc, Connell, K., Umali-Deininger D., and de Haan, C., 2008.Are the poor Willing to Pay for Livestock services? Evidence from Rural India. Indian Journal of Agricultural Economics. 58(1): $84-99$.

Ahuja, V., and Redmond, E., 2001. Economic and policy issues in livestock service delivery to the poor, Background paper 
for the FAO project memorandum "Propoor livestock policy initiative : Fostering the policy dialogue in support of equitable, safe and clean livestock farming".

Birthal, P.S., and Ali, J., 2005. "Potential of livestock sector in rural transformation, In: Rural Transformation in India: The Role of Non-farm Sector", Manohar Publishers and Distributors, New Delhi.

Chand, S., Meena, B.S., and Verma, H. C., 2013. A Study on Farmers' Satisfaction with Delivery of Veterinary Services. Indian Journal of Animal Research. 48 (1): 67-70.

Kumar, S. R., Reddy, K.V.R., and Rao, B.S., 2006. Opinion towards privatization of Veterinary Services. Indian Journal of Animal Research. 40: 143-146.

Linder-Pelz, S., 1982. Towards a theory of patient satisfaction. International Journal of Health Care Assurance, 8(6): 32

Sangameswaran, R., and Prasad, S., 2016. Extent of Willingness to Pay for Dairy Husbandry Services by Milk Producers of Salem District of Tamil Nadu. Indian
Research Journal of Extension Education, 16(3), 67-72.

Shweta, K., 2014. Artificial Insemination for Dairy Development in Ranchi District of Jharkhand. Indian Research Journal Extension Education. 14 (1): 90-92.

Singh, R.P., and Hazell, P.B.R., 1993. Rural Poverty in the Semi-Arid Tropics of India: Identification, Determinants and Policy Interventions. Economic and Political Weekly, 28(12 \&13): 9-15.

Thornton, P.K., Kruska, R.L., Henninger, N., Kristjanson, P.M., Reid, R.S., Atieno, F.,Odero, A N., and Ndegwa, T.,2002."Mapping poverty and livestock in the developing world, ILRI, Nairobi, Kenya" (http://www.ilri.cgiar. org/InfoServ/Webpub/Fulldocs/Mappov erty/index.htm).

Umali, D.L., Feder, G., and de Haan, C., 1992. The balance between public and private sector activities in the delivery of livestock services World Bank discussion paper 163 the World Bank, Washington DC.

\section{How to cite this article:}

Sangameswaran, R. and Sunitha Prasad. 2018. A Case of Milk Producers Perception towards Extent of Input Supply and Preventive Services by Milk Marketing Agencies in Salem District of Tamilnadu, India. Int.J.Curr.Microbiol.App.Sci. 7(03): 1430-1439.

doi: https://doi.org/10.20546/ijcmas.2018.703.171 